\title{
PLASTIC WASTE CONVERSION TO LIQUID FUELS OVER MODIFIED-RESIDUAL CATALYTIC CRACKING CATALYSTS: MODELING AND OPTIMIZATION USING HYBRID ARTIFICIAL NEURAL NETWORK - GENETIC ALGORITHM
}

\author{
Istadi $^{*}$, Luqman Buchori, and Suherman \\ Laboratory of Energy and Chemical Process Engineering, \\ Department of Chemical Engineering, Faculty of Engineering, Diponegoro University, \\ Jl. Prof. H. Sudharto, SH., Semarang, 50239 Indonesia, Telp: 024-7460058, Fax: 024-76480675 \\ ${ }^{*}$ Corresponding author: istadi@ undip.ac.id
}

\begin{abstract}
The plastic waste utilization can be addressed toward different valuable products. A promising technology for the utilization is by converting it to fuels. Simultaneous modeling and optimization representing effect of reactor temperature, catalyst calcinations temperature, and plastic/catalyst weight ratio toward performance of liquid fuel production was studied over modified catalyst waste. The optimization was performed to find optimal operating conditions (reactor temperature, catalyst calcination temperature, and plastic/catalyst weight ratio) that maximize the liquid fuel product. A Hybrid Artificial Neural Network-Genetic Algorithm (ANN-GA) method was used for the modeling and optimization, respectively. The variable interaction between the reactor temperature, catalyst calcination temperature, as well as plastic/catalyst ratio is presented in surface plots. From the GC$M S$ characterization, the liquid fuels product was mainly composed of $C_{4}$ to $C_{13}$ hydrocarbons.
\end{abstract}

Keywords: artificial neural network; central composite design; genetic algorithm; optimization; plastic waste; Residual Catalytic Cracking

\begin{abstract}
Abstrak
KONVERSI LIMBAH PLASTIK MENJADI BAHAN BAKAR CAIR DENGAN METODE PERENGKAHAN KATALITIK MENGGUNAKAN KATALIS BEKAS YANG TERMODIFIKASI: PEMODELAN DAN OPTIMASI MENGGUNAKAN GABUNGAN METODE ARTIFICIAL NEURAL NETWORK DAN GENETIC ALGORITHM. Pemanfaatan limbah plastik dapat dilakukan untuk menghasilkan produk yang lebih bernilai tinggi. Salah satu teknologi yang menjanjikan adalah dengan mengkonversikannya menjadi bahan bakar. Permodelan, simulasi dan optimisasi simultan yang menggambarkan efek dari suhu reaktor, suhu kalsinasi katalis, dan rasio berat plastik/katalis terhadap kinerja produksi bahan bakar cair telah dipelajari menggunakan katalis bekas termodifikasi Optimisasi ini ditujukan untuk mencari kondisi operasi optimum (suhu reaktor, suhu kalsinasi katalis, dan rasio berat plastik/katalis) yang memaksimalkan produk bahan bakar cair. Metode Hybrid Artificial Neural Network-Genetic Algorithm (ANN-GA) telah digunakan untuk permodelan dan optimisasi simultan tersebut. Inetraksi antar variabel suhu reaktor, suhu kalsinasi katalis, dan rasio berat plastik/katalis digambarkan dalam bentuk plot surface. Berdasarkan karakterisasi GC-MS, produk bahan bakar yang diperoleh terdiri dari komponen-komponen hidrokarbon $C_{4}-C_{13}$.
\end{abstract}

Keywords: artificial neural network; central composite design; genetic algorithm; optimasi; limbah plastik; Residual Catalytic Cracking

\section{INTRODUCTION}

Plastic waste constitutes a growing social problem, because of the loss of natural resources, the environmental pollution, and the depletion of landfill space. The waste minimization, reuse, recycling, and energy recovery are important to ensure the carbon cycle in the world. In recent years, the feedstock recycling has arisen as a promising alternative aimed at the conversion of plastic wastes into valuable chemicals and fuels. High temperature pyrolysis and 
cracking of waste thermoplastic polymers, such as polyolefines, polyethylene (PE), and polypropylene (PP) are well-known and environmentally benign methods of their utilization. Thus, catalytic cracking of plastic waste over acidic solids (zeolites-based catalysts) has been proposed as an interesting solution subject to reduce the cracking temperature (Manos et al., 2000).

Catalytic conversion of plastic waste to fuels and chemicals has proven to be a promising procedure depending on catalyst, reactor type, and operating conditions. Thermal pyrolysis is a typical chemical recycling process, enabling production of monomers, mainly ethylene, propene, and butene from waste plastics at higher temperature. In case of the cracking processes, their main products are fuels fractions, gaseous hydrocarbons, and liquid mixtures of hydrocarbons boiling in the range of temperatures $\sim 35-360^{\circ} \mathrm{C}$ (gasoline and light gas oils) as well as the solid carbon residues, similar to coke. The plastic waste cracking can be converted toward different interesting products (olefinic gases, gasolines, heavy oils, etc.). The procedure becomes an efficient route which utilizes waste stuffs to produce any useful products.

Inline with the phenomena, use of catalysts allows the plastic degradation pathway to be modified that would affects the process temperature (reduce temperature). Comprehensively, two positive effects are expected by incorporation of a catalyst into the reaction medium: (i) a reduction of the cracking temperature, and (ii) suitable control of the selectivity, which enables the formation of more-valuable products. Accordingly, a great variety of heterogeneous catalysts have been investigated for the catalytic cracking of plastics, such as: (a) silica alumina (Songip et al., 1993; Ishihara et al., 1990; Sakata et al., 1999), (b) conventional commercial zeolites (HZSM-5, HBeta, HY, etc.) (Manos et al., 2000; Songip et al.,1993; Sakata et al.,1999; Marcilla et al.,2007), (c) fresh and spent FCC catalysts, (Ali et al., 2002; Cardona and Corma, 2000; Akpanudoh et al., 2005; De la Puente et al., 2002; De la Puente et al., 1997), (d) mesostructured catalysts (MCM-41, FSM-16, Al-SBA-15, AlUTD-1) (Serrano et al., 2000; Aguado et al., 1997; Serrano et al., 2000), and (e) superacid solid catalyst $\left(\mathrm{ZrO}_{2} / \mathrm{SO}_{4}{ }^{2-}\right)$ (Liu and Meuzelaar,1996). Among the different catalysts tested for the conversion of polyolefinic plastics, zeolites are one of the most extensively studied. However, the catalytic cracking of plastic polymers over conventional zeolites is limited by the bulky nature of the plastic polymer molecules and the small size of the zeolite micropores. This obstacle can be avoided by using larger-pore catalysts, such as mesoporous MCM41 , or zeolites with small crystal sizes $(100 \mathrm{~nm})$ that exhibit a high proportion of external surface acid sites. Thus, a significant decrease in the crystal size of ZSM5 zeolite has led to an enhanced activity in the cracking of both polyolefins and lube oils.

The great majority of the previous works are focused on the catalyst finding particularly on fresh catalyst leading to the appropriate catalyst for plastic or polymer conversion to fuels and chemicals. In terms of modeling and optimization, there are no researchers concerned on improving the process itself, such as finding the optimum operating conditions with respect to maximum reactor performances. The modeling and optimization were important to find optimum operating conditions with respect to maximum yield or conversion to fuels. In this paper, the simultaneous modeling and optimization using hybrid artificial neural network-genetic algorithm method is developed in order to reduce cost of the complex cracking research.

The present work is intended to develop simultaneous modeling and optimization algorithm to find optimal operating conditions (reactor temperature, calcination temperature, and catalyst/plastic sample ratio) with respect to maximum performance of plastic waste conversion to liquid fuels over modified residual catalytic cracking (RCC) waste catalyst. The modeling and optimization used a hybrid artificial neural network-genetic algorithm (ANN-GAalgorithm). A Central Composite Design (CCD) method was utilized to design the experimental works for training the ANN model.

\section{MATERIALS AND METHOD Catalyst Preparation}

A modified spent catalyst from Residual Catalytic Cracking (RCC) plant was used in this research in order to utilize the catalyst waste. The catalyst waste was obtained from a RCC petrochemical company in Indonesia which is abundant in availability. Modification of the used catalyst was performed using some physical and chemicals treatments. The catalyst was dried overnight at $110^{\circ} \mathrm{C}$ in an oven (MEMMERT) and therefore was calcined at certain temperature for 3 hours in a programmable box furnace (NEY VULCAN 3-550). The calcination temperatures were set based on experimental design $\left(479-621^{\circ} \mathrm{C}\right)$. The resulted powder was crushed into the desired size (42-62 mesh).

The plastic waste samples were mixed polypropylene (PP) and polyethylene (PE) from drinking water bottle and drinking water cup with ratio of PP:PE is 1:1, respectively. The plastic samples were cut to form smaller chips. Twenty five grams of mixed plastic waste was used in each experimental run. Catalyst/plastic ratio used in each experimental run was designed based on the experimental design (0.060.11 ), while cracking time of each run was 60 minutes.

\section{Catalyst Testing and Liquid Fuel Characterization}

The catalytic performance of plastic waste conversion to fuels was tested in a fixed bed reactor equipped with an electric heater (local brand-self fabricated) as depicted in Figure 1. The reactor was built from stainless steel tube with a diameter of 1 inch which put inside the electric heater. Reactor temperature was measured and controlled by a digital temperature controller (Autonics). 


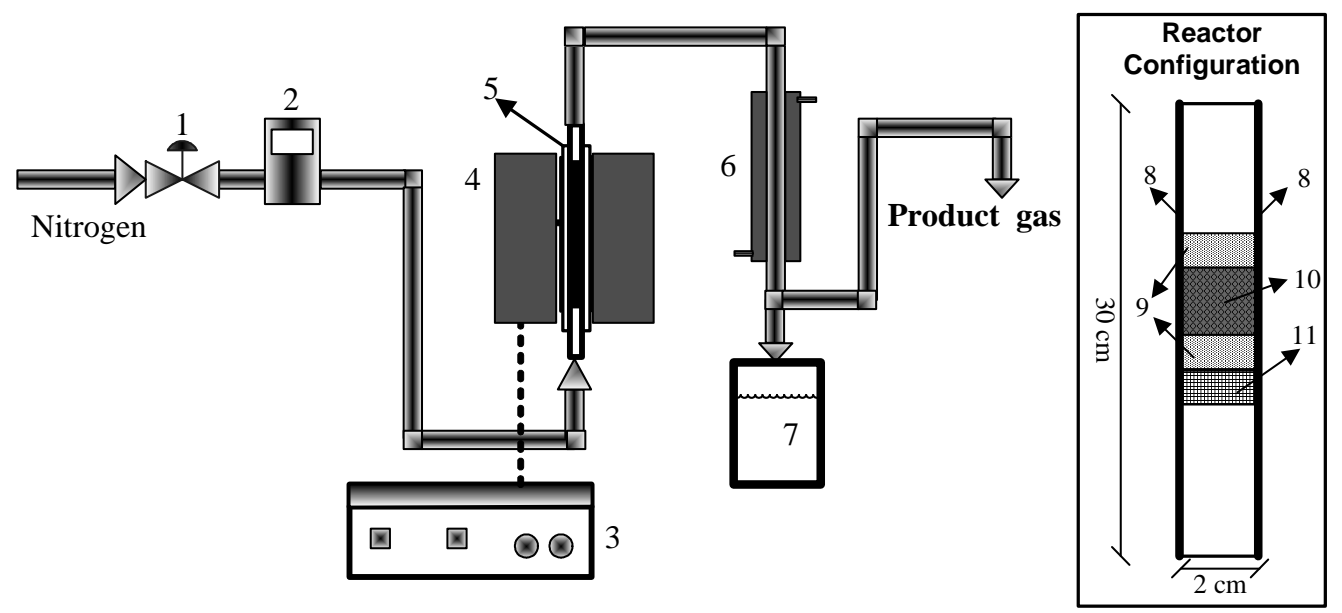

Figure 1. Experimental setup of catalytic cracking of plastic waste, (1) Gate Valve, (2) Flowmeter,

(3) Temperature Controller, (4) Split Tube Furnace, (5) Fixed Bed Reactor, (6) Condensor, (7) Liquid fuel trap,

(8) Stainless steel Tube, (9) Catalyst, (10) Plastic sample, (11) Glass wool

A part of the catalyst was put in the center of the reactor (below the plastic sample). The glass wool was plugged below the catalyst to avoid overflow of the liquid plastic. The glass wool was also put above the plastic sample. Here, the plastic vapor should be confirmed to be able to flow inside the glass wool packed. Another part of the catalyst was put above the last glass wool packed in order to more crack the plastic vapor. Before reaction, the reactor inside was flushed with nitrogen flow for 15 minutes. The reactor was heated up to certain temperature (reactor temperature) with respect to the experimental design $\left(479-621^{\circ} \mathrm{C}\right)$. Vapor product (cracked substance) was flowed through a condenser (temperature of $5^{\circ} \mathrm{C}$ ) to condense the vapor to form liquid fuel, while the non condensable gas was collected in a gas sampling pot. The liquid product was stored in a flask. Therefore, the liquid fuel product was analyzed using a gas chromatography-mass spectrometry (GC-MS) (SHIMADZU QP2010S) equipped with RTX-5 column. The liquid fuel product was also analyzed using infrared spectroscopy on a SHIMADZU FT-IR spectroscopy. The spectrum of pure chloroform was used as the background and liquid fuel product sample was dissolved in chloroform and used for FTIR analysis. Single beam spectra $\left(4000-400 \mathrm{~cm}^{-1}\right)$ of the samples were obtained, and corrected against the background spectrum of chloroform, to present the spectra in absorbance units at a resolution of $16 \mathrm{~cm}^{-1}$.

\section{Experimental Design for Training Data}

A central composite rotatable design was employed for designing experimental works to provide training data for Artificial Neural Network model developed (Montgomery, 2001). Three independent variables or process parameters, namely reactor temperature, catalyst calcination temperature, and catalyst/plastic weight ratio, were selected as controlled factors. Ranges of independent variables were chosen based on conditions obtained from the variables screened prior to optimization. These experimental data are used for validating the Artificial
Neural Network model for the plastic conversion process. The sequence of experiment was randomized in order to minimize the effects of uncontrolled factors.

Development of Simultaneous Algorithm for Modeling and Optimization

Artificial Neural Network (ANN) has been widely used in chemical engineering applications for modeling of complex process, process control, and fault detection and diagnosis (Stephanopoulos and Han, 1996; Huang et al., 2003; Radhakrishnan and Suppiah, 2004; Fissore et al., 2004). The combination of ANN and Genetic Algorithm (GA) has been used by previous researchers for modeling and optimization of integrated process (Nandi et al., 2002; Nandi et al., 2004; Ahmad et al., 2004). The detail hybrid algorithm for simultaneous modeling and optimization using ANN and GA has been developed (Istadi and Amin, 2007; Istadi and Amin, 2006) for complex plasma reactor application. They reported that the hybrid ANN-GA technique is a powerful method for process modeling and optimization which is better than other technique such as response surface methodology (RSM), particularly for complex process model.

The RSM method proposes a quadratic model as empirical model for representing effect of independent variables toward the targeting response. Therefore, all models which may not follow the quadratic trend are forced to the quadratic model. Disadvantages of the RSM method are improved by Hybrid Artificial Neural Network-Genetic Algorithm (ANN-GA) method. In the last method, empirical mathematical modeling of catalytic cracking is conducted by Artificial Neural Network, while the optimization of operating conditions is performed using Genetic Algorithm method.

In general, four main steps are developed in the ANN training process: assembling the training data, creating the network object, training the network, and simulating the network response to new inputs. 
Schematic of the feedforward neural network with backpropagation training used in the model development is depicted in Figure 2, while detail algorithm of the hybrid ANN-GA was developed elsewhere (Istadi and Amin, 2007; Istadi and Amin, 2006).

The detail stepwise procedure for the hybrid ANN-GA algorithm modified from the previous publications (Istadi and Amin, 2007; Istadi and Amin, 2006) is depicted schematically in Figure 3. The fit quality of the ANN model

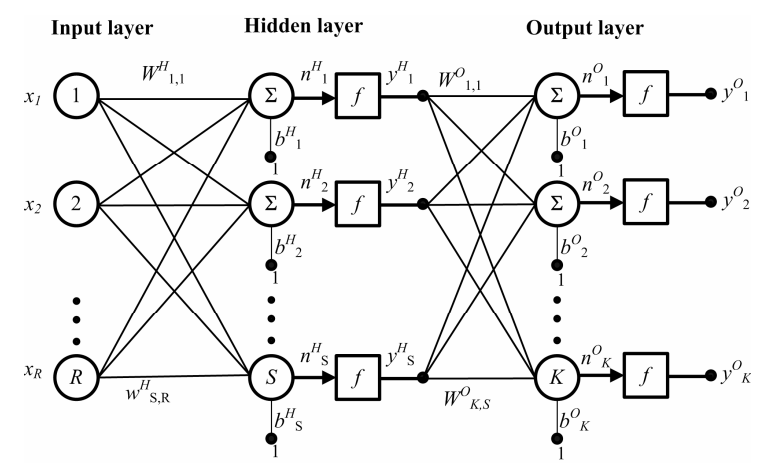

Figure 2. A schematic diagram of the multi-layered perceptron (MLP) in feedforward neural network with backpropagation training

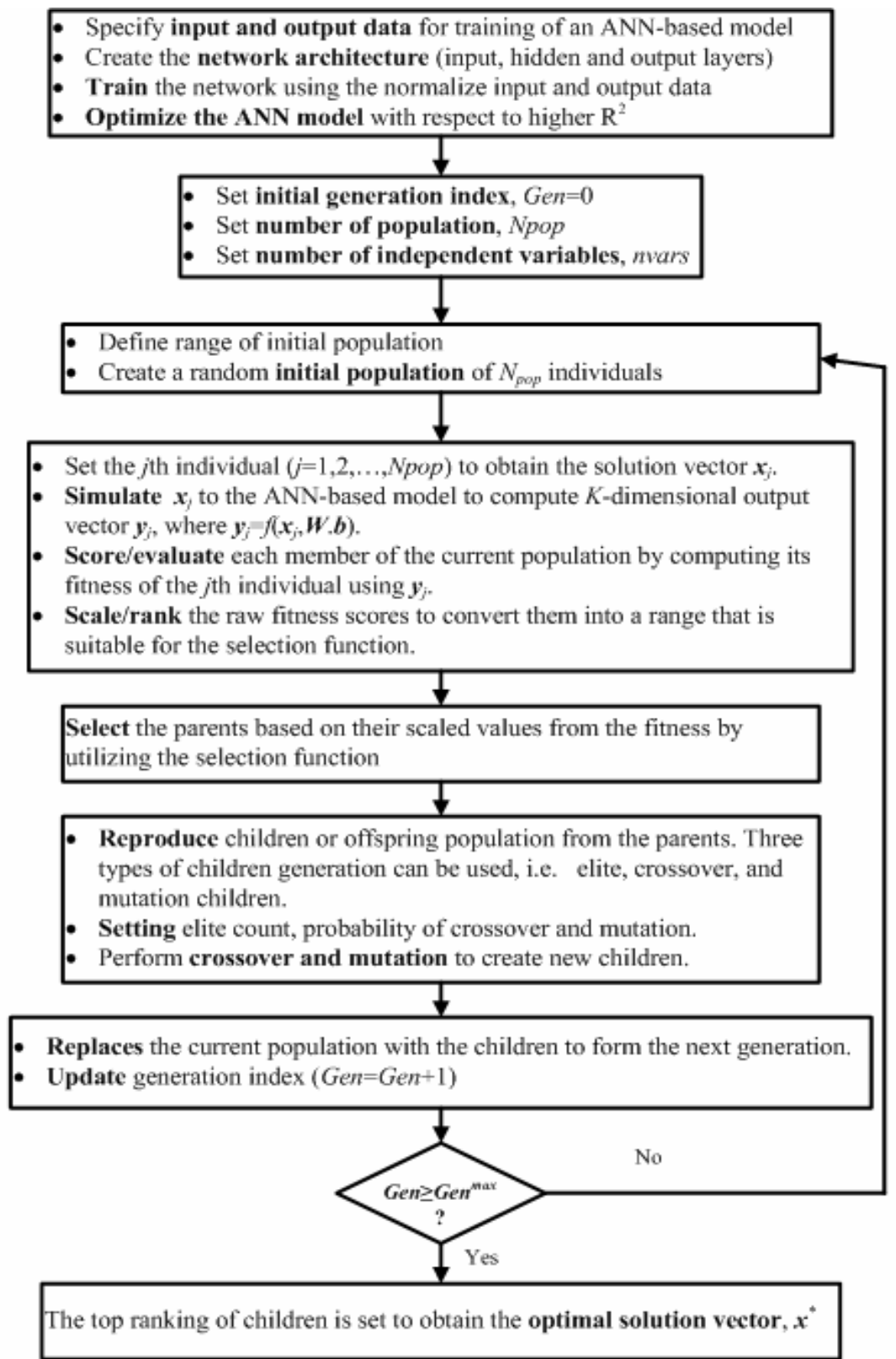

Figure 3. Flowchart of the hybrid ANN-GA algorithms for simultaneous modeling and optimization 
RESULTS AND DISCUSSION

Development of Algorithm for Simultaneous Artificial Neural Network-Genetic Algorithm (ANN-GA) Method

Detailed kinetics of the stated multiple reactions in the conservation equations are required in development of a phenomenological model reactor. Due to the tedious procedures involved in obtaining the requisite kinetic information within the phenomenological model, the exclusively data-based ANN-GA methods were chosen for maximizing the yield of liquid and gas fuels. In this study, simultaneous modeling and optimization of complex process within cracking process for conversion of plastic waste to liquid fuels over catalytic fixed bed reactor is addressed. Purpose of the optimization is to find optimum operating conditions with respect to maximum yields of liquid fuel. Accordingly, three operating factors, namely reactor temperature, catalyst calcinations temperature, and catalyst: plastic sample ratio, were used as input space of the ANN model. Meanwhile, the yield of liquid and gas fuels are assigned as output variables of the ANN model which will be maximized.

Regarding the simultaneous modeling and optimization algorithm using the hybrid ANN-GA (Figure 3), the accuracy of the hybrid method was validated by a set of simple discrete data developed from a simple quadratic equation as an example (i.e. $\left.y=-2 x^{2}+15 x+5\right)$. From the testing, the determination coefficient $\left(\mathrm{R}^{2}\right)$ of the method closes to 1 means that the empirical method (ANN-GA) has a good fitting, while the relative error of the optimized results (comparison between GA results and analytical solution) are below $10 \%$. In overall, a researcher only enters discreet data of multi input (multi independent variables) and single output (single dependent variables) or multi output. After the simulation, the researcher gets a robust simulator of the process as well as the optimized operating conditions (input variables) to obtain the maximum performances.

In this research, the ANN model performance for comparison between targeted yield and predicted yield for liquid fuel model is shown in Figure 4. In the figure, observed values of liquid fuel yield are compared to predicted values of the yield. From the figures, the ANN models are fit well to the experimental data which proven by high determination coefficients $\left(\mathrm{R}^{2}\right)$ of 0.95 . The high $\mathrm{R}^{2}$ value implies a good fitting between the observed (experimental) and the predicted values, which means that the ANN-based model is suitable for representing the real process. Indeed, the hybrid ANN models are suitable for simulating performance of the plastic waste catalytic cracking to liquid fuel over modified spent catalyst. The good fitting is also revealed by low mean square error (MSE) during training of the model.

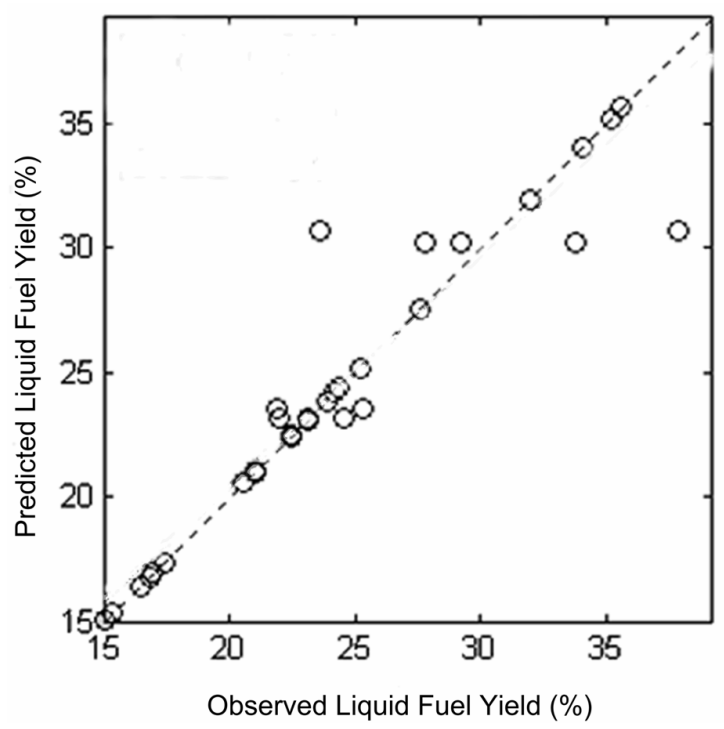

Figure 4. Observed versus predicted values for ANN model fitting of liquid fuel yield $\left(\mathrm{R}^{2}=0.95\right)$

\section{Effect of Operating Parameters on Liquid Fuel Product Yield}

This section presents simulation results on effect of operating conditions, i.e. reactor temperature, catalyst calcination temperature, and catalyst/plastic weight ratio toward liquid fuel yield in a catalytic fixed bed reactor. The simulation was carried out by varying the operating parameters (reactor temperature, catalyst calcination temperature, and catalyst/plastic weight ratio) according to the experimental design (central composite design (CCD)) presented in Table 1. The experimental data used for training the ANN model are presented in Table 2 including the yield of liquid fuel and the yield of gas fuel as targeted performances.

Table 1. Range and level of independent variables using Central Composite Design (CCD)

\begin{tabular}{lccccc}
\hline \multicolumn{1}{c}{ Factors } & \multicolumn{5}{c}{ Range and Levels } \\
\cline { 2 - 6 } & $(-\alpha)$ & $(-1)$ & $(0)$ & $(+1)$ & $(+\alpha)$ \\
\hline Reactor Temperature $\left[{ }^{\circ} \mathrm{C}\right]$ & 479 & 500 & 550 & 600 & 621 \\
Calcination Temperature $\left[{ }^{\circ} \mathrm{C}\right]$ & 479 & 500 & 550 & 600 & 621 \\
Catalyst/Plastic Weight Ratio $[\mathrm{g} / \mathrm{g}]$ & 0.9 & 1.0 & 1.25 & 1.5 & 1.6 \\
\hline
\end{tabular}


Table 2. Results of experiments based on the central composite design

\begin{tabular}{|c|c|c|c|c|c|}
\hline \multirow[b]{2}{*}{ Run No. } & \multicolumn{3}{|c|}{ Independent Variables } & \multicolumn{2}{|c|}{ Dependent Variables } \\
\hline & $\begin{array}{l}\text { Reactor Temperature } \\
\left({ }^{\circ} \mathrm{C}\right)\end{array}$ & $\begin{array}{c}\text { Calcination } \\
\text { Temperature }\left({ }^{\circ} \mathrm{C}\right)\end{array}$ & $\begin{array}{c}\text { Catalyst/Plastic } \\
\text { Ratio (g/g) }\end{array}$ & $\begin{array}{l}\text { Liquid Fuel } \\
\text { Yield (\%) }\end{array}$ & Gas Fuel Yield (\%) \\
\hline 1 & 500 & 500 & 0.08 & 25.20 & 21.0 \\
\hline 2 & 600 & 500 & 0.08 & 35.62 & 15.00 \\
\hline 3 & 500 & 600 & 0.08 & 24.60 & 18.40 \\
\hline 4 & 600 & 600 & 0.08 & 27.56 & 15.30 \\
\hline 5 & 550 & 479 & 0.08 & 39.24 & 16.40 \\
\hline 6 & 550 & 621 & 0.08 & 31.96 & 16.80 \\
\hline 7 & 479 & 550 & 0.08 & 21.00 & 11.36 \\
\hline 8 & 621 & 550 & 0.08 & 37.92 & 21.90 \\
\hline 9 & 550 & 550 & 0.08 & 31.76 & 23.52 \\
\hline 10 & 550 & 550 & 0.08 & 33.76 & 24.56 \\
\hline 11 & 550 & 550 & 0.08 & 32.34 & 25.23 \\
\hline 12 & 550 & 550 & 0.08 & 33.12 & 23.20 \\
\hline 13 & 550 & 550 & 0.08 & 31.87 & 23.40 \\
\hline 14 & 500 & 550 & 0.07 & 23.09 & 16.94 \\
\hline 15 & 500 & 550 & 0.10 & 20.57 & 17.34 \\
\hline 16 & 600 & 550 & 0.07 & 34.42 & 20.09 \\
\hline 17 & 600 & 550 & 0.10 & 24.18 & 22.45 \\
\hline 18 & 479 & 550 & 0.08 & 35.23 & 24.38 \\
\hline 19 & 621 & 550 & 0.08 & 23.57 & 25.26 \\
\hline 20 & 550 & 550 & 0.06 & 27.75 & 21.98 \\
\hline 21 & 550 & 550 & 0.11 & 23.83 & 21.04 \\
\hline 22 & 550 & 550 & 0.08 & 34.04 & 22.44 \\
\hline 23 & 550 & 550 & 0.08 & 29.25 & 23.07 \\
\hline 24 & 550 & 550 & 0.08 & 29.67 & 20.33 \\
\hline 25 & 550 & 550 & 0.08 & 30.18 & 23.63 \\
\hline 26 & 550 & 550 & 0.08 & 27.69 & 20.42 \\
\hline
\end{tabular}

Note: Pressure : atmospheric; total cracking time: 60 minutes

${ }^{*}$ The yields data (with catalyst) was calculated from experimental yields results minus the yields without catalyst.

Effect of the reactor temperature and the ratio of catalyst to plastic weight on the liquid fuel yield is demonstrated in Figure 5, while effect of the reactor and the catalyst calcination temperatures is depicted in Figure 6.

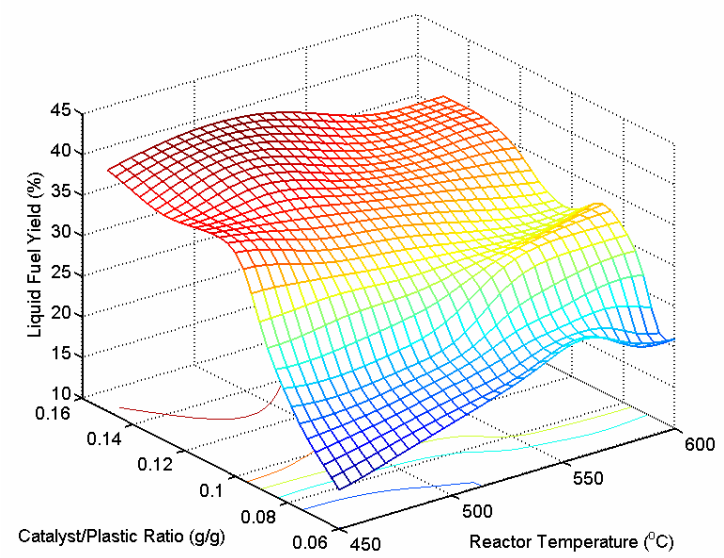

Figure 5. Surface plot of liquid fuel yield model as function of reactor temperature and catalyst/plastic sample ratio

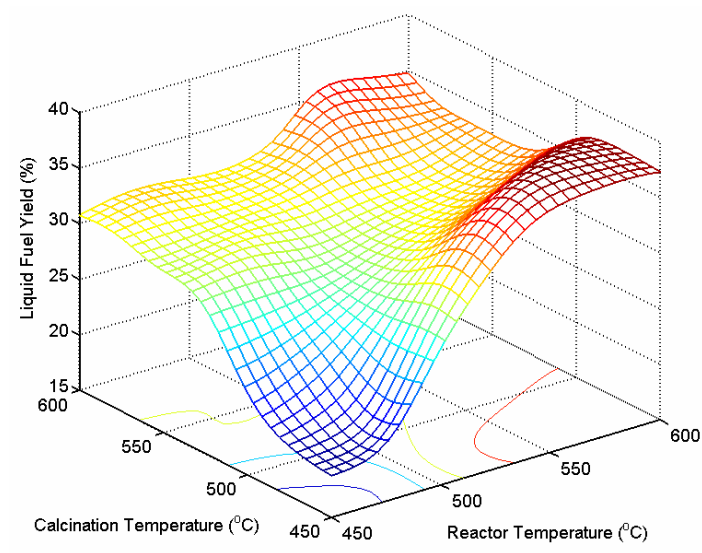

Figure 6. Surface plot of liquid fuel yield model as function of reactor temperature and calcination temperature

From the figures, the liquid fuel yield is affected by reactor temperature and catalyst/plastic weight ratio significantly. The liquid fuel product yield is also affected by catalyst calcination temperature slightly. The reactor temperature gives most 
significant effect on the production of liquid fuel product. That's true because the reactor temperature relates with the energy supply required for the catalytic cracking process. In thermal cracking process (without catalyst), a higher reactor temperature (more than $850^{\circ} \mathrm{C}$ ) is needed to fulfill the required energy for cleavage of carbon-carbon bonding in polymer materials. However in this catalytic cracking, the catalyst gives alternative routes which lowers activation energy of the cracking process. The thermal energy is required for activation of the catalyst itself to do the catalytic cracking process. The catalyst gives alternative routes of reaction mechanism so that the activation energy is lower.

In this research, the catalyst used is a modified spent-catalyst obtained from residual catalytic cracking plant. The catalyst calcination temperature provides sufficient energy for opening the active sites in the catalyst pore and leads to high surface area of the catalyst. In calcination of the catalyst, formation of Brønsted acid sites within the catalyst structure, having important roles in hydrocarbon cracking process, is controlled significantly by optimum calcination temperature. The presence of Brønsted acid sites ensures that carbon-carbon cleavage occurs in the catalytic cracking. The acid sites could be proven by catalyst characterization method of pyridine adsorption on Brønsted acid sites in infrared band at $1540 \mathrm{~cm}^{-1}$ (Tanabe et al., 1989; Zheng et al., 2009). The Brønsted acidity depends on the zeolite structure and the chemical composition of the molecular sieves (Lercher et al., 2008; Auroux et al., 1993). The catalytic cracking is essentially carbenium ion chemistry. Due to the high temperature of reactor or the presence of Brønsted acid sites in the modified spent RCC catalyst, the carbenium ions may split into a smaller carbenium ion and an alkene molecule. Thus, carbon-carbon bond scission occurs in the carbenium ion atom. The next task for using spent catalyst is how to regenerate the strong Brønsted acid sites in the modified catalyst. The correlation of operating parameters, i.e. reactor temperature and catalyst calcination temperature, is important in term of regenerating the strong Brønsted acid sites within the catalyst surface. The weight ratio of catalyst to plastic sample is related to weight hourly space velocity of the catalytic cracking reaction.

\section{Optimization of Operating Parameters to} Maximize Liquid Fuel Product Yield

Optimization plot of three independent variables (reactor temperature; catalyst calcination temperature; and catalyst/plastic weight ratio) using Genetic Algorithm method is depicted in Figure 7. In the optimization, the Genetic Algorithm showed a powerful method. By using this tool, a global maximum operating condition is achieved better than a local optimum as obtained from ordinary or differential-based optimization method. From the optimization, the optimal operating conditions, i.e. reactor temperature of $561^{\circ} \mathrm{C}$, catalyst calcinations temperature of $477^{\circ} \mathrm{C}$, and catalyst/plastic weight ratio of 0.08 , were produced with respect to maximum liquid product yield of $39.58 \%$.
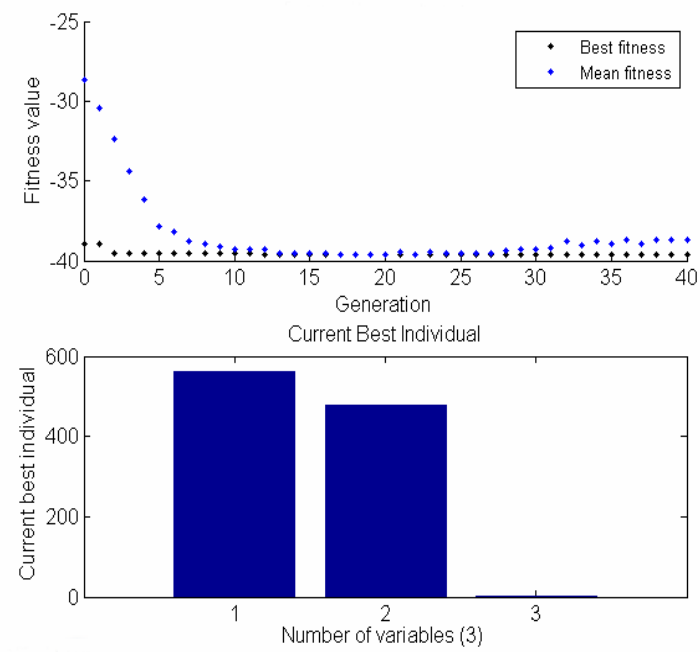

Figure 7. Optimization plot of three variables (reactor temperature; catalyst calcination temperature; and catalyst/plastic weight ratio) using Genetic Algorithm

\section{Characterization of Liquid Fuel Product}

Identification and composition of hydrocarbon components in the liquid fuel product were determined using GC-MS as presented in Table 3. From the table, the modified RCC catalyst waste could produce the hydrocarbon-based liquid fuels $\left(\mathrm{C}_{4}-\mathrm{C}_{13}\right)$ as listed in the Table 3. Hydrocarbons range of the liquid product could be controlled by varying the reactor temperature and type of the catalyst.

Table 3. Identification and composition of main hydrocarbons components of liquid fuels product using GC-MS analysis

\begin{tabular}{ccc}
\hline Retention time (minutes) & Main Identified Compound & Composition $(\%)$ \\
\hline 2.225 & $\mathrm{C}_{4} \mathrm{H}_{8}$ (2-Methyl-1-propene) & 3.33 \\
2.408 & $\mathrm{C}_{5} \mathrm{H}_{10}$ (2-Methyl-2-butene) & 3.44 \\
2.650 & $\mathrm{C}_{6} \mathrm{H}_{12}$ (3-Methyl-2-pentene) & 8.08 \\
3.208 & $\mathrm{C}_{7} \mathrm{H}_{14}$ (3-Methyl-2-hexene) & 13.66 \\
3.983 & $\mathrm{C}_{7} \mathrm{H}_{8}$ (Methyl benzene) & 10.96 \\
5.133 & $\mathrm{C}_{9} \mathrm{H}_{18}$ (Propil-Cyclohexane) & 10.26 \\
5.308 & $\mathrm{C}_{9} \mathrm{H}_{18}(2,4$-dimethyl-1-Heptane) & 12.00 \\
15.175 & $\mathrm{C}_{13} \mathrm{H}_{28}$ (n-tridecanol) & 38.27 \\
\hline
\end{tabular}


Catalyst configuration and reactor design (depicted in Figure 1) is also essential towards controlling range of hydrocarbons product with respect to the effective contact between liquid and vaporized plastic sample and the catalyst bed. In this research, the catalyst was divided into two portions, i.e. below plastic sample and above plastic sample as depicted in Figure 1. The advance investigation of configuration of sample and catalyst within the reactor will be published in next articles. The configuration of catalyst and plastic sample is purposed to enhance the contact between liquefied and vaporized plastic samples and the catalyst surface effectively.

The liquid fuel product was also characterized by FT-IR method as depicted in Figure 8.

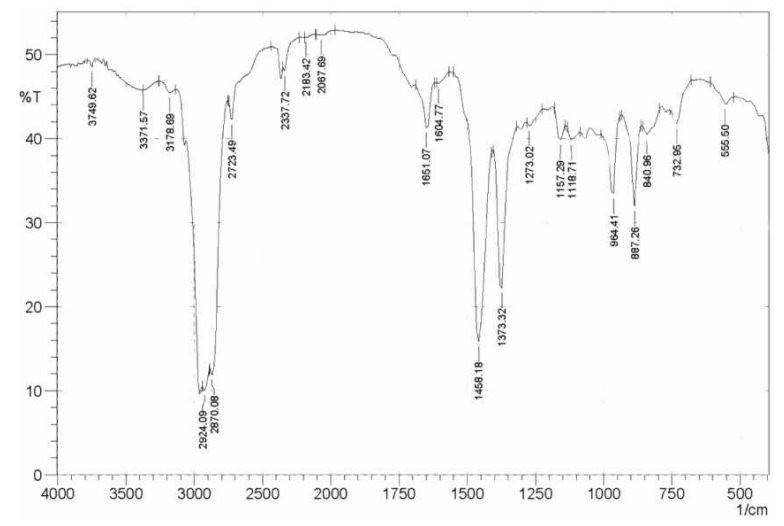

Figure 8. FT-IR characterization of liquid fuel product

From the figure, the strong sharp peaks at $2970-2924 \mathrm{~cm}^{-1}$ is assigned to stretching vibration of $\mathrm{C}-\mathrm{H}$ bonds (Paradkar and Irudayaraj, 2002; Kazanskii, 2007; Siddiqui, 2009), while the lower peak at $2337 \mathrm{~cm}^{-1}$ is ascribed to the combinations between the bending and twisting $\mathrm{CH}_{2}$ vibrations and the double bond vibrations (Siddiqui, 2009). The peaks between 3000 and $2800 \mathrm{~cm}^{-1}$ indicate the presence of $-\mathrm{CH}_{3},-\mathrm{CH}_{2}$, and $\mathrm{C}-\mathrm{H}$ functional groups, which are indicative of aliphatic species such as alkanes (Siddiqui, 2009). The $\mathrm{C}=\mathrm{C}$ absorbance peak at $1651 \mathrm{~cm}^{-1}$ confirms that alkene groups are present. The presence of peak in 1373 to $1458 \mathrm{~cm}^{-1}$ due to the deformation vibrations of $\mathrm{C}-\mathrm{H}$ bonds confirms the presence of aliphatic groups. A sharp weak peak at $732 \mathrm{~cm}^{-1}$ and two sharp medium peaks at 887 and 964 $\mathrm{cm}^{-1}$ indicating $\mathrm{C}-\mathrm{H}$ cyclic deformations which suggest either aromatic.

\section{CONCLUSIONS}

Simultaneous modeling and optimization of liquid fuel production from plastic waste over modified RCC catalyst waste was studied. From the Hybrid Artificial Neural Network-Genetic Algorithm simulation, it is shown that the operating parameters that most affected the responses were reactor temperature followed by the catalyst calcination temperature. From the optimization, the optimal operating conditions, i.e. reactor temperature of $561^{\circ} \mathrm{C}$, catalyst calcinations temperature of $477^{\circ} \mathrm{C}$, and catalyst/plastic weight ratio of 0.08 , were produced with respect to maximum liquid product yield of $39.58 \%$. From product characterization using GC-MS and FT-IR, it can be suggested that the catalytic cracking of plastic sample using modified spent RCC catalyst produces liquid fuels $\left(\mathrm{C}_{4}-\mathrm{C}_{13}\right)$.

\section{ACKNOWLEDGMENT}

The authors would like to express their sincere gratitudes to the Directorate General for Higher Education (DIKTI) Republic of Indonesia for the financial support received under the project of HIBAH KOMPETENSI GRANT YEAR 2009-2010.

\section{REFERENCES}

Aguado, J., Sotelo, J.L., Serrano, D.P., Calles, J.A., and Escola, J.M., (1997), Energy Fuels, 11, pp. 12251231

Ahmad, A.L., Azid, I.A., Yusof, A.R., and Seetharamu, K.N., (2004), Comp. Chem. Eng., 28, pp. 2709-2715

Akpanudoh, N.S., Gobin, K., and Manos, G., (2005), J. Mol. Catal. A: Chem., 235, pp. 67-73

Ali, S., Garforth, A.A., Harris, D.H., Rawlence, D.J., and Uemichi, Y., (2002), Catal. Today, 75, pp. $247-$ 255

Auroux, A., Tuel, A., Bandiera, J., Ben Taarit, Y., and Guil, J.M., (1993), Appl. Catal. A, 93, pp. 181-190.

Cardona, S.C. and Corma, A., (2000), Appl. Catal. B: Env., 25, pp. 151-162

De la Puente, G., Arandes, J.M., and Sedran, U.A., (1997), Ind. Eng. Chem. Res., 36, pp. 4530-4534

De la Puente, G., Klocker, C., and Sedran, U., (2002), Appl. Catal. B., 36, pp. 279-285

Fissore, D., Barresi, A.A., and Manca, D., (2004), Chem. Eng. Sci., 59, pp. 4033-4041.

Huang, K., Zhan, X.L., Chen, F.Q., and Lü, D.W., (2003), Chem. Eng. Sci., 58, pp. 81-87.

Ishihara, Y., Nanbu, H., Ikemura, T., and Takesue, T., (1990), Fuel, 69, pp. 978-984

Istadi and Amin, N.A.S., (2006), Ind. Eng. Chem. Res., 45, pp. 6655-6664

Istadi and Amin, N.A.S., (2007), Chem. Eng. Sci., 62, pp. 6568-6581

Kazanskii, V. B., (2007), Kinetics Catal., 48, pp. 479489 
Lercher, J. A., Jentys, A., and Brait, A., (2008), Mol. Sieves, 6, pp. 153-212.

Lin, Y.H. and Yang, M.H., (2005), J. Mol. Catal. A: Chem., 231, pp. 113-122

Liu, K. and Meuzelaar, H.L.C., (1996), Fuel Process. Technol., 49, pp. 1-15

Manos, G., Garforth, A., and Dwyer, J., (2000), Ind. Eng. Chem. Res., 39, pp. 1198-1202

Marcilla, A., Gomez.Siurana, A., and Valdes, F., (2007), J. Anal. Appl. Pyrolysis, 79, pp. 433-442

Marcilla, A., Gomez-Siurana, A., and Valdes, F., (2008), Microporous Mesoporous Mater., 109, pp. 420-428

Montgomery, D.C., (2001), Design and Analysis of Experiments, John Wiley \& Sons, New York.

Nandi, S., Badhe, Y., Lonari, J., Sridevi, U., Rao, B.S., Tambe, S.S., and Kulkarni, B.D., (2004), Chem. Eng. J., 97, pp. 115-129.

Nandi, S., Mukherjee, P., Tambe, S.S., Kumar, R., and Kulkarni, B.D., (2002), Ind. Eng. Chem. Res., 41, pp. 2159-2169.

Paradkar, M.M. and Irudayaraj, J., (2002), Int. J. Dairy Technol., 55, pp. 127-132

Radhakrishnan, V.R. and Suppiah, S., (2004), In Proceeding of the 18th Symposium of Malaysian
Chemical Engineers, Universiti Teknologi Petronas, Perak, Malaysia.

Sakata, Y., Uddin, M.A., and Muto, A., (1999), J. Anal. Appl. Pyrolysis, 51, pp. 135-155

Serrano, D.P., Aguado, J., and Escola, J.M., (2000), Appl. Catal. B: Env., 25, pp. 181-189

Serrano, D.P., Aguado, J., and Escola, J.M., (2000), Ind. Eng. Chem. Res., 39, pp. 1177-1184

Siddiqui, M.N., (2009), J. Hazard. Materials, 167, pp. 728-735.

Songip, A.R., Masuda, T., Kuwahara, H., and Hashimoto, K., (1993), Appl. Catal. B, 2, pp. 153-164

Stephanopoulos, G. and Han, C., (1996), Comp. Chem. Eng., 20, pp. 743-791.

Tanabe, K., Misono, M., Ono, Y., and Hattori, H., (1989), New Solid Acids and Bases, Elsevier B.V., Amsterdam.

Uemichi, Y., Kashiwaya, Y., Tsukidate, M., Ayame, A., and Kanoh, H., (1983), Bull. Chem. Soc. Jpn., 56, pp. $2768-2773$

Uemichi, Y., Nakamura, J., Itoh, T., and Sugioka, M., (1999), Ind. Eng. Chem. Res., 38, pp. 385-390

Zheng, X.D., Dong, H.J., Wang, X., and Shi, L., (2009), Catal. Lett., 127, pp. 70-74 